Wzniostość $i$ makabra w literackich obrazach śmierci, red. Michał Kuran, Łódź 2014, „Analecta Literackie i Językowe", t. IV.

Michat SADOWSKI ${ }^{1}$

Uniwersytet Łódzki

\title{
ŚMIERĆ JAKo OCZYSZCZENIE DUSZY w TwórCZOŚCI SARAH KANE
}

Lata 90. XX wieku przyniosły nieoczekiwany zwrot w brytyjskim teatrze dramatycznym. Znudzenie patetycznymi i klasycznymi sztukami spowodowało pojawienie się dramatów, które w swej wymowie zaczęły być brutalne, a nawet grubiańskie, przesiąknięte obrazami przemocy, seksem, pełne okrucieństwa, podejmujące tematy marginalne, z punktu widzenia mieszczańskiego widza. Zjawisko to oznaczało proces wprowadzania nowej estetyki teatralnej, nowego stylu dramatopisarstwa, który został określony jako Nowy brutalizm (Cool Britannia), znany również jako nowy realizm czy estetyka plugastwa ${ }^{2}$. Początkowo ten nurt opanował przede wszystkim przemysł rozrywkowy (kino, muzykę pop, telewizję), nurt ten w końcu dotarł do tradycyjnego teatru, ulegając tym samym deformacji. Artyści tworzący w duchu Nowego brutalizmu pragnęli, by widzowie oswoili się z okrucieństwem, które miało wyzwolić zasoby człowieczeństwa istniejące jeszcze w widzach — ich zdaniem zepsutych i nieczułych. Wystawiane dramaty były drastyczne w wyrazie, określane angielskim sformułowanie „in-yer-face” (,jak w mordę”) ${ }^{3}$ — sztuki brutalne, niekonwencjonalne w doborze formy, tematu i języka.

Dramatopisarze tworzący w duchu Nowego brutalizmu to Mark Ravenhill ze sztuką Shopping and Fucking, Jez Butterwoth z Mojo oraz Sarah Kane, debiutująca w roku 1995 sztuką Zbombardowani (Blasted) ${ }^{4}$. Młoda pisarka okazała się niezwykle kontrowersyjna i niekonwencjonalna. Początkowo została niedoceniona. Po premierze Zbombardowanych krytyka uznała, że ukazanie przez angielską dramatopisarkę na deskach teatru scen gwałtu (na kobiecie i mężczyźnie), masturbacji, defekacji, oślepienia czy kanibalizmu służy tylko obyczajowej prowokacji, szokowaniu publiczności ${ }^{5}$. Jednak było inaczej, Kane w jednym z wywiadów stwierdziła:

\footnotetext{
${ }^{1}$ Michał Sadowski — absolwent filologii polskiej oraz kulturoznawstwa na Wydziale Filologicznym UŁ, inspektor bankowy w mBanku, przewodniczący Koła Naukowego Literatury i Kultury Staropolskiej w roku akad. 2012/2013. W kręgu jego zainteresowań znajduje się literatura baroku (szczególnie interesują go wątki i motywy mitologiczne oraz poezja wizualna), a także literatura najnowsza.

${ }^{2}$ A. Sierz, Jak w morde, „Dialog” 1999, nr 3, s. 143.

${ }^{3}$ Tamże.

${ }^{4}$ Tamże, s. 144.

${ }^{5}$ G. Saunders, „Kochaj mnie lub zabij”. Sarah Kane i teatr skrajności, Warszawa-Kraków 2010, s. 5.
} 
Zawsze pisałam tylko po to, żeby wyrwać się z piekła — i nigdy mi się to nie udało. Ale gdy tkwisz tam, oglądasz coś i myślisz, że to najdoskonalszy wyraz piekła, jaki znamy, to dochodzisz do wniosku, że być może warto było ${ }^{6}$.

Jak się okazało, Kane nie udało się wyrwać ze szponów depresji i zarówno dla niej, jak i dla jej bohaterów jedynie miłość i śmierć stały się rzeczywistą możliwością odzyskania spokoju, osiągnięcia celu w życiu.

Większość sztuk pisarki wyrażała ekspresję wielkiego okrucieństwa i cierpienia. Poetyka upoważnia do porównania ich z teatrem okrucieństwa Antonina Artauda oraz teatrem katastroficznym Howarda Barkera ${ }^{7}$. Obsesja na punkcie zbrodni i przemocy prowadzi także do skojarzeń z obrazami znanymi z innego medium sztuki, jakim jest film, konkretnie porównywano autorkę Zbombardowanych do Quentina Tarrantino. Istnieje jednak zasadnicza różnica — rozlew krwi u Kane służy nie tylko, jak u reżysera Pulp Fiction, estetycznej prowokacji, kulturowej grze, ironii i czarnemu humorowi czy szokowaniu odbiorcy, ale ma również wymiar moralny i oczyszczający ${ }^{8}$, działa jak katharsis. W przypadku Zbombardowanych Kane pyta o moralne znaczenie wojny (tu wojny domowej w byłej Jugosławii ${ }^{9}$ ), siły miłości w Łaknąć i w Oczyszczonych, czy wyrwania się z monotonii życia w sposób radykalny w Miłości Fedry. Nasuwa się pytanie, w jaki sposób odbierać sztuki Kane; jedni uważali, że są przesycone pornografią, inni wskazywali na oczyszczającą siłę jej utworów. Sama autorka lekceważyła zakazy łączenia różnych porządków poznawczych, wyznaczników scenicznego decorum czy społecznego tabu. Wykorzystała dwuznaczność współistnienia seksu i śmierci w kulturowym (a szczególnie pop-kulturowym) imaginarium, wyprowadzając z ich związku poczucie metafizycznego lęku i walor wzniosłości ${ }^{10}$.

Pełne okrucieństwa i makabry sceny w sztukach Kane powinny być odczytywane metaforycznie. Sceny przemocy są skonstruowane niezwykle sugestywnie — przerażające obrazy odsyłają do okrucieństwa niemożliwego do wyrażenia w konwencji realistycznej, ich emocjonalna intensywność wyrażona została już na poziomie języka. Dialogi dramatyczne pisarki wyróżniają się porażającą i sensualną siłą, to w nich rodzą się obrazy przemocy i bólu ${ }^{11}$.

Ian, główny bohater Zbombardowanych, cały czas czeka na śmierć, brata się z nią poprzez ułożenie się w grobie dziecka, czuje wówczas paradoksalnie błogość. Jeszcze przed tym wykopie nieskalane i czyste ciałko dziecka i nakarmi się nim — bohater tym samym zbruka niewinność, próbując zrzucić z siebie ciężar odpowiedzialności. Doko-

\footnotetext{
${ }^{6}$ Tamże, s. 9.

${ }^{7}$ Tamże, s. 29.

${ }^{8}$ Tamże, s. 40-41.

${ }^{9}$ Tamże, s. 48.

${ }^{10}$ D. Ratajczakowa, W krysztale i w ptomieniu. Studia i szkice o dramacie i teatrze, Wrocław 2006, s. $180,183$.

${ }^{11}$ M. Kwaśniewska, Od wstrętu do sublimacji. Teatr Krzysztofa Warlikowskiego w świecie teorii Julii Kristevej, Kraków 2009, s. 66.
} 
na tego również za pomocą własnej śmierci; w jego przypadku stała się ona pokutą za grzechy i za gwałt na Cate. Ich relacja jest oparta na konwencji ofiary i kata ${ }^{12}$, jednak pod koniec sztuki postaci zamieniają się rolami. Ian prosi o wyzwolenie i przebaczenie Cate, która staje się niezależną i wyzwoloną kobietą, zaś swoją kobiecość zaczyna wykorzystywać jako narzędzie, by w ogóle przetrwać. Paradoksalnie pod wpływem gwałtu dojrzewa ${ }^{13}$.

W świecie, w którym żyją bohaterowie tej sztuki, panuje wszechobecny chaos, spowodowany wybuchem wojny. Ludzie dopuszczają się bestialskich czynów, czego przykładem jest postać Żołnierza, który chwali się swą niemoralnością:

\section{Żołnierz:}

[...]

Złamałem kobiecie kark. Pchnąłem ją nożem pomiędzy nogi, przy piątym pchnięciu zgruchotałem jej kręgosłup ${ }^{14}$.

Dokonuje on również gwałtu na Ianie, który wcześniej wykorzystał Cate. Ian zostaje ukarany za swoje czyny utratą wzroku. Bohater-dziennikarz, utracił najważniejszy zmysł. Początkowo Kane chciała, by tę postać wykastrowano, jednak wydało się jej to zbyt melodramatyczne ${ }^{15}$. Niczym Gloster z Króla Leara Szekspira czy mitologiczny Edyp Sofoklesa, Ian traci wzrok i prosi o wyzwolenie z męki Cate. Bohaterka pośrednio jest odpowiedzialna za śmierć Iana. Podaje mu pistolet Żołnierza, którym wcześniej celował do Iana. Samobójstwa główny bohater jednak nie popełnia, gdyż Cate wyjmuje uprzednio naboje $\mathrm{z}$ broni ${ }^{16}$. Jak informują didaskalia, Ian cierpi, przypomina tym samym konającego Chrystusa i oszalałego z bólu wariata:

IAN leży bardzo spokojnie, osłabł z głodu.

Ciemność.

Światło.

Wyrywa krzyż z podłogi, wyrzuca deski i wyjmuje ciało niemowlęcia.

Zjada je.

Wkłada materiał, w który owinięte było niemowlę z powrotem do dziury.

Moment, po nim Ian włazi w dziurę i kładzie się z głową wytkniętą nad podłogę.

Umiera $\mathrm{z}$ ulgą ${ }^{17}$

${ }^{12}$ M. Lachman, Co mówi dialog, czyli o kłopotach komunikacyjnych w najnowszym dramacie brytyjskim, [w:] Dialog w dramacie, red. W. Baluch, Kraków 2004, s. 103.

${ }^{13}$ M. Lachamn, Brzytwa po oczach, Kraków 2007, s. 143.

${ }^{14}$ S. Kane, Zbombardowani, przekł. P. Wodziński, P. Łysak, Warszawa 1999.

${ }^{15}$ G. Saunders, $d z$. cyt., s. 83.

${ }^{16}$ Tamże, s. 92.

${ }^{17}$ S. Kane, dz. cyt., sc. 5, s. 99. 
Autorka w jednym z wywiadów wspomniała, że Ian zostaje pod koniec sztuki z jednej strony odkupiony, z drugiej ukarany, zyskując tym status bohatera-cierpiętnika, bo doświadczył więcej niż inni. Podobnie jak bohater romantyczny, cierpiał i dzięki temu stał się wyjątkowy ${ }^{18}$.

Druga sztuka Kane Miłość Fedry, opierająca się na rdzeniu tragedii Seneki ${ }^{19}$, przypomina i rozwija wątki z pierwszego dzieła autorki. Główny bohater Hipolit przypomina Iana. Jest to rozżalony nihilista ${ }^{20}$ bez pomysłu na dalszą egzystencję. Obaj mężczyźni są pod wpływem kobiet, jednak to nie one decydują o ich przemianie. Finalnie dokonuje się ona za sprawą cierpienia bohaterów i w końcu śmierci. Hipolit jest przykładem „antybohatera”, który dopiero po uduszeniu, wykastrowaniu i pozbawieniu wnętrzności przez rozwścieczony tłum i Tezeusza uwalnia się od życia opartego na konsumpcjonizmie, nudzie, braku satysfakcji, życiu, które objawia się zmanierowaniem, traktowaniem ludzi i rzeczy jak kolejnych używek. Wszak Hipolit jest synem króla i ma wszystkiego pod dostatkiem, królewicz zastanawia się na co dzień, w jaki sposób „czas wypełnić bzdetami, gadżetami, pierdółkami”21.

Życie Hipolita to porażająca pustka oparta na ubezwłasnowolniającej rutynie. Fedra ujmuje to w jednym zdaniu podczas rozmowy z Doktorem, zwracając uwagę na jego hedonistyczną postawę: „Ogląda filmy. I uprawia seks” ${ }^{22}$. Podobnie jak Ian, Hipolit czeka na przełom w życiu, na coś, co nada sens jego istnieniu. Cierpi na przymus życia, wyzwoleniem okaże się męka i śmierće ${ }^{23}$. Jego frustracja, niechęć do życia wzrasta, gdy niemal każdy z poddanych uwielbia go, co poświadcza córka Fedry Strofa podczas rozmowy z matką:

STROFA Oni go kochają. Wszyscy go kochają. A on za to nimi gardzi ${ }^{24}$.

Cenniejsza jest dla niego brutalna prawda, zamiast pustych pochlebstw. Dlatego w końcowych scenach sztuki bohater wyraża podziw dla wolnej woli, rewolucji, zamętu, które dają nadzieję zmiany.

Tragedia dotyka również Fedrę. Znudzona i namiętna kobieta, której mąż jest wiecznie nieobecny, czuje się samotna. Miłość do pasierba potęguje jej dramat niespełnienia. Pragnie za wszelką cenę, nawet za cenę śmierci, posiąść Hipolita, który gardzi macochą. Fedra jest gotowa do największych poświęceń; odrzucona przez pasierba postanawia zamiast swojego ciała oddać mu swoje życie — jest w tym pewną i świadomą kobietą. Jej śmierć daje paradoksalnie życie - Hipolit, choć na chwilę, wyrywa

${ }^{18}$ G. Saunders, dz. cyt., s. 99-100.

${ }^{19}$ Tamże, s. 107.

${ }^{20}$ Tamże, s. 110.

${ }^{21}$ S. Kane, Mitość Fedry, przekł. M. Semil, „Dialog” 1999, nr 9.

${ }^{22}$ M. cyt.

${ }^{23}$ E. Wąchocka, Milczenie w dwudziestowiecznym dramacie, Kraków 2005, s. 232.

${ }^{24}$ S. Kane, Mitosíc Fedry, sc. 3, s. 7. 
się z marazmu ${ }^{25}$. Jednak jego szczęście nie trwa długo; fałszywe oskarżenie Hipolita o gwałt na Fedrze skutkuje rozpadem monarchii i rozpętaniem się zamieszek na ulicy. Ten przewrót przynosi śmierć całej rodziny królewskiej: Hipolit zostaje uduszony, zadźgany nożem, rozczłonkowany, Tezeusz gwałci i zabija Strofę, Fedra wiesza się, a sam Tezeusz podrzyna sobie gardło.

Okrucieństwo wydarzeń, paradoksalnie cieszy znudzony i brutalny tłum przed pałacem. Dla zabawy dokonują oni zbezczeszczenia zwłok Hipolita (jego ciało zostaje skopane, oplute, rozdarte). Scena śmierci królewicza stanowi jego gloryfikację, jest aktem uwznioślenia, bohater cierpi niczym Chrystus, podobnie jak Ian w Zbombardowanych. Hipolit jest jednak ofiarą, a nie jak Ian oprawcą, cierpi za błąd Fedry i zostaje oczyszczony z win. Jego oczyszczenie nie mogło się dokonać za sprawą spowiedzi czy po prostu rozmowy z Kapłanem (którego gwałci), Hipolit wprost powie: „pieprzyć Boga”, bo w niego nie wierzy. Syn Tezeusza świadomie wybiera śmierć, nie słucha rad księdza i Strofy, by bronić swojej godności i odeprzeć zarzuty o gwałt na Fedrze ${ }^{26}$. Z radością godzi się na publiczną egzekucję. W jej trakcie przeistoczeniu ulega w rytualnym krwawym sparagmos jego ciało, przynosząc mu w momencie ostatecznego unicestwienia pierwszą i jedyną chwilę wyzwolenia, epifanii, poczucia swobody, faustycznego pragnienia zatrzymania tego stanu na zawsze. „Gdyby takich chwil było więcej” ${ }^{27}$ mówi umierając. Szaleństwo jego unicestwienia staje się znakiem prawdziwej katharsis i uwznioślenia ${ }^{28}$. Wywołanie katharsis - oczyszczenia przez szok, wstręt, zgrozę, ingerencja w „prywatność” widza, Kane osiąga przede wszystkim za pomocą języka, który wprowadza efekt emocjonalny, jaki przynosi jego specyficzna tu waloryzacja (relacja podmiot/abiekt jej tekstów) - pisarka podąża tu za Julią Kristevą ${ }^{29}$.

Spotęgowane obrzydzenie i wstręt, jakiego doświadczamy w kolejnej sztuce Oczyszczeni, ma wydobyć widza ze stanu obojętności na krzywdę. Kontrowersyjne tematy (ślub homoseksualistów czy kazirodcza namiętność), uczucie wstrząsu psychicznego i fizycznego spazmu towarzyszy czytelnikowi niemal bez przerwy ${ }^{30}$. Autorka podkreślała wielokrotnie w wywiadach, że makabryczne sceny w jej utworach miały swoje niefikcyjne pierwowzory (inspiracje stanowily wydarzenia na stadionach sportowych czy doniesienia z wojny w Bośni) ${ }^{31}$. Takie nagromadzenie wizji okrucieństwa i przemocy nie pozwala zachować spokoju i obojętności. Wiedząc o bezmiarze rzeczywistego bestialstwa, z góry współczujemy bohaterom i rozumiemy ich czyny.

\footnotetext{
${ }^{25}$ A Pobratyn, Przemiany wizerunku kobiety $w$ dramacie na przykładzie postaci Fedry, „Prace Naukowe Akademii im. Jana Długosza. Seria: Filologia Polska. Historia i Teoria Literatury”, tom XI, red. E. Hurnikowa, L. Rożek, Częstochowa 2009, s. 216.

${ }^{26}$ G. Saunders, dz. cyt., s. 116.

${ }^{27}$ S. Kane, Mitość Fedry...

${ }^{28}$ E. Wąchocka, dz. cyt., s. 232.

${ }^{29}$ Zob. J. Kristeva, Potegga obrzydzenia. Esej o wstręcie, przekł. M. Falski, Kraków 2007.

${ }^{30}$ M. Kwaśniewska, dz. cyt., s. 64.

${ }^{31}$ Tamże, s. 63-64.
} 
Tytuł sztuki Oczyszczeni przywołuje kontekst zbawienia przez miłość i śmierć. Oprawca, mefistofeliczny Tinker, przekształca były uniwersytet w rodzaj obozu śmier$\mathrm{ci}^{32}$, podaje się za lekarza i pomaga na swój sposób zagubionym bohaterom. W tym zakładzie nie odnajdziemy jednak schronienia, przypomina on bardziej pułapkę ${ }^{33}$. Specyficzne zabiegi, których dokonuje na postaciach dramatu Tinker, powoduja oczyszczenie, ale przeprowadzone w sposób bardzo radykalny. Grace zostaje wyleczona ze swojej tęsknoty do brata — poddaje się prymitywnej operacji zmiany płci (Tinker obcina jej piersi i przeszczepia genitalia) ${ }^{34}$; Carlowi ucina język z powodu kłamstwa, które ów język wypowiedział, jego niezdecydowania i zdrady wobec Roda, zmusza go również do połknięcia obrączki — to symboliczny akt śmierci miłości ${ }^{35}$, a później systematycznie odcina mu ręce, by uniemożliwić zapisanie wyznań, nogi, by nie mógł tańczyć z Rodem. Wywiera również presję na Robina, by zjadł czekoladki przeznaczone dla Grace, które bohater wymiotuje — zwracając tym samym wszystko to, czego nauczyła bohatera przyjaciółka ${ }^{36}$.

Okrucieństwo, które towarzyszy torturom zadawanym przez Tinkera bohaterom, to zmetaforyzowany obraz niemożności spełnienia miłości, wyrażenia w słowach jej doświadczenia, ma ono także wyleczyć z depresji i samotności jego samego; Tinker, krzywdząc swoje ofiary, przygląda się im jak w lustrze. Walczy w ten sposób ze swoimi własnymi wstrętami i lękami ${ }^{37}$. Żaden z jego zabiegów nie powoduje jednak przemiany w nim samym, bo wszystkie jego ofiary są jak popękane lustra, wszystkie mają problemy osobowościowe ${ }^{38}$, są niedookreślone, nie potrafią wyrazić swoich emocji, dlatego Tinker nie widzi dla nich miejsca w świecie, eliminuje ich w okrutny sposób, tak jak niszczy sam sposób porozumienia język w symbolicznym geście podpalenia książek.

Obok Tinkera najbardziej doświadczona zostaje Grace. Wyobraża sobie ona cierpienie i śmierć, które ma złagodzić jej smutek czy zagubienie. Dramat tej postaci został uchwycony w kilku aspektach. Bohaterka jest samotna, ma zaburzenia psychiczne (można mieć wrażenie, że cierpi na schizofrenię i depresję — jest bita przez niewidzialnych mężczyzn) oraz najtrudniejsze: problemy z tożsamością płciową — Grace zmienia płeć i często myli siebie ze swoim bratem Grahamem.

Tortury, których doświadczają bohaterowie Kane, przypominają mękę Chrystusa. Carl w Oczyszczonych przyjmuje pozę sugerującą proces przybijania do krzyża, rozkłada ręce i opuszcza głowę, jakby wisiał na krzyżu ${ }^{39}$. Oskarżenie Hipolita i niesłuszne

\footnotetext{
${ }^{32}$ G. Saunders, dz. cyt., s. 133.

${ }^{33}$ Tamże, s. 134.

${ }^{34}$ Tamże, s. 137.

35 Tamże, s. 139.

${ }^{36}$ Tamże, s. 79.

${ }^{37}$ M. Kwaśniewska, dz. cyt., s. 77.

${ }^{38}$ M. cyt.

${ }^{39}$ Tamże, s. 81.
} 
skazanie na śmierć kojarzy się ze skazaniem Jezusa przez Piłata pod wpływem presji tłumu. Jego śmierć jest symboliczna, gdyż umiera długo, tłum zgromadzonych sam wymierza mu sprawiedliwość - próbuje udusić bohatera za pomocą krawatu ściągniętego z szyi dziecka, a więc śmierć Hipolita jest okraszona niewinnością ${ }^{40}$. Ian natomiast ginie męczeńską śmiercią i zostaje złożony w grobie po dziecku, które zjadł. Wszystkie te nawiązania i konteksty uwydatniają z jednej strony cierpienie fizyczne, z drugiej wielkie udręczenie psychiczne bohaterów, wyznaczając moment graniczny $\mathrm{w}$ ich życiu ${ }^{41}$. Ich śmierć nie jest łatwa, ale oczyszcza $\mathrm{z}$ win i sprawia, że dostępują uwznioślenia, moment śmierci jest epifanią, metafizycznym gestem, objawieniem prawdy ich losu, tożsamości.

Świat u Kane jest dotknięty krańcowym cierpieniem i nieszczęściem, ulega całkowitej degradacji i dezintegracji. Tym samym przypomina piekło ${ }^{42}$. Autorka Oczyszczonych pragnie, by czytelnik uczestniczył w mękach i cierpieniu jej bohaterów poprzez trwogę i litość, które są współczesnym odpowiednikiem klasycznej katharsis ${ }^{43}$. Okrucieństwo odegrane na scenie, jak w koncepcji Artauda, staje się dla publiczności wyzwaniem i nadzieją. Odsłonięcie na scenie tego, co ukryte — pragnienia przemocy i atrakcyjności zła — oczyszcza emocje. Widz musi uświadomić sobie, że ludzie pozbawili, pozbawiają i będą pozbawiać się swojej godności. Agresja i przemoc, uważane za instynktowne zachowania zwierząt, stają się coraz bliższe ludziom.

Przemoc u Kane stanowi „sposób bycia” jej bohaterów. Sama artystka dokonuje aktu agresji wobec klasycznego decorum, bezkarności i bezpieczeństwa widza - to wszystko zostaje zachwiane właśnie przez przemoc, za pomocą „pisania wprost”. Rzekomo prowokacyjny charakter jej tekstów pokazuje w istocie rzeczywistość, w jakiej funkcjonują zwykli ludzie. W świecie pisarki wszystko wolno, a jeśli wszystko człowiekowi wolno, to oznacza, że na końcu czeka go śmierć ${ }^{44}$.

Czy faktycznie $\mathrm{w}$ świecie ucywilizowanym, zmierzającym ku lepszemu, nie ma miejsca na moralność i miłosierdzie? Dramatopisarka widzi nadzieję i siłę tylko w miłości, jednak najpierw zaleca uporządkowanie chaosu i zwrócenie uwagi na dehumanizację człowieka.

\footnotetext{
${ }^{40}$ J. Kozłowska, „O możliwości czytania poza kategoria gender”. Biblijne tropy $w$ dramatach Sarah Kane, [w:] Życie księgi. Biblia a dramat i teatr wspótczesny, red. E. Partyga, M. Prussak, Warszawa 2010, s. 187.

${ }^{41}$ M. Kwaśniewska, $d z$. cyt., s. 81.

${ }^{42}$ D. Ratajczykowa, $d z$. cyt., s. 184.

${ }^{43}$ M. cyt.

${ }^{44}$ H. Krall, Powiedzieć prościej, „Gazeta Wyborcza” 2002 nr 22, wydanie z 26 stycznia 2002, dodatek „Wysokie Obcasy”, nr 4, s. 4.
} 
Michał Sadowski

\section{Death as a Cleansing of the Soul in the Work of Sarah Kane}

\section{Summary}

The article draws attention to the reversal dominant that is the death in works of Sarah Kane. The scandalous writer presented a different kind of love and death. As a representative of "the Cool Britannia” in her plays engulfs the reader with the cruelty that is clean heroes and cause to the people woke up real humanity. Is due to torture, disease, and death can save the world and its inhabitants? The writer as eloquent and innovative attempts to answer this question because of its small, but rich in creativity, prematurely terminated. 